\title{
SCHEMES OF SOLID-PHASE SPECTROPHOTOMETRIC ANALYSIS OF FOOD OBJECTS
}

\author{
Elizaveta Kostenko \\ Department of Food chemistry \\ National University of Food Technologies \\ 68 Volodymyrska str., Kyiv, Ukraine, 01601 \\ Kostenkoelizaveta@ukr.net \\ Elena Butenko \\ Department of Food chemistry \\ National University of Food Technologies \\ 68 Volodymyrska str., Kyiv, Ukraine, 01601 \\ butenko0656@ukr.net \\ Larisa Arseneva \\ Department of Food Expertise \\ National University of Food Technologies \\ 68 Volodymyrska str., Kyiv, Ukraine, 01601 \\ ars-I@ukr.net
}

\begin{abstract}
The aim of research is development of approaches to the development of schemes for microelement analysis of food objects. This will make it possible to monitor food quality by simple and affordable methods in factory laboratories.

Based on data on the immobilization of dyes on ion exchangers and on the interaction of metal ions or their complexes with immobilized dyes, solid-phase spectrophotometric (SPS) and photometric methods for determining metal ions in food technology, biotechnology and the environment have been developed.

Techniques are sensitive. High distribution coefficients $(\mathrm{D} \geq 104 \mathrm{~cm} 3 / \mathrm{g})$ of metal ions help to reduce the detection limit when using immobilized dye as compared to the reaction in solution. Based on the detection limit values (DLV), the proposed sorption-spectrophotometric methods for determining metal ions are second only to the atomic absorption (AAS) determination of $\mathrm{Cd}$ (II) and $\mathrm{Hg}$ (II) ions and the polarographic determination of Cd (II) ions. However, the proposed methods for the determination of these metal ions are sufficient for the determination of Cd (II) and $\mathrm{Hg}$ (II) ions in food products at the MPC level. In the case of determination of $\mathrm{Pb}$ (II), $\mathrm{Zn}$ (II), $\mathrm{Cu}$ (II), Fe (III) ions, the developed methods have advantages over standard methods for determination of metal ions in food products, since they make it possible to determine these ions at a level $\leq 0.1 \ldots 0.5 \mathrm{MPC}$;

Ion exchangers with immobilized dyes and solid-phase spectrophotometric determination methods with their participation are environmentally safe, since they do not require the use of toxic organic reagents; are simple in execution and economically advantageous because of the low cost of used materials and reagents.

The correctness of the results of the determination by the developed methods is proved: by comparison with the results of determinations on standard methods at various analysis objects using the method of additives, standard samples. The relative standard deviation of the developed SPS determination procedures does not exceed 0.10 , which indicates satisfactory reproducibility of the results. The developed methods exceed the majority of standard and best analogs, known from the literature, for sensitivity and selectivity. The used methods of analysis are characterized by the simplicity of the experiment, ecological safety, do not require special expensive equipment, highly qualified personnel and a stationary laboratory.
\end{abstract}

Keywords: spectrophotometric determination of elements, food quality control, hybrid methods of analysis.

\section{Introduction}

Complicating the ecological situation in Ukraine, increasing the requirements for the quality of food and raw materials, the need to expand methods for diagnosing the initial stages of human diseases are associated with the ingress of a large number of toxic metals into food products, drinking water and other environmental objects. Therefore, it is important not only to create low-waste and non-waste environmentally friendly technologies, but also new effective methods of analytical control [1, 2]. 
To determine the microquantities of metals, use such complex, highly sensitive methods of analysis as atomic emission, mass spectrometric, neutron-activation, atomic absorption, X-ray fluorescence and luminescent methods. They assume the availability of expensive equipment, which is serviced by highly qualified employees in a stationary laboratory.

The possibilities of simple spectrophotometric determinations are limited by insufficient selectivity and sensitivity, the complexity of the concentration of the ions being determined and the sample preparation $[3,4]$. This adversely affects the metrological characteristics of photometric techniques (DLV, reproducibility, accuracy, speed).

The use of hybrid sorption spectroscopy methods using solid-phase (SP) complexing reagents allows to achieve much better results [5-13].

Therefore, the aim of research is development of approaches to the development of schemes for microelement analysis of food objects. This will make it possible to monitor food quality by simple and affordable methods in factory laboratories.

\section{Materials and Methods}

Reagents. The initial $0.1 \mathrm{~mol} / 1$ solutions of the salts $\mathrm{Cu}(\mathrm{II}), \mathrm{Pb}(\mathrm{II}), \mathrm{Zn}(\mathrm{II}), \mathrm{Fe}(\mathrm{III}), \mathrm{Hg}(\mathrm{II})$, $\mathrm{Cd}(\mathrm{II})$ were prepared by dissolving the samples: $\mathrm{CuSO}_{4} \times 5 \mathrm{H}_{2} \mathrm{O}$ (c. p.), $\mathrm{Zn}^{0}$ i Cd $\mathrm{Cd}^{0}$ (odd parts) in 0.1 and $1.0 \mathrm{~mol} / \mathrm{H} \mathrm{H}_{2} \mathrm{SO}_{4}$; $\mathrm{Pb}\left(\mathrm{NO}_{3}\right)_{2}, \mathrm{Fe}\left(\mathrm{NO}_{3}\right)_{3} \times 6 \mathrm{H}_{2} \mathrm{O}, \mathrm{Hg}\left(\mathrm{NO}_{3}\right)_{2} \times 0.5 \mathrm{H}_{2} \mathrm{O}$ (c.p) in $0.1 \mathrm{~mol} / 1 \mathrm{HNO}_{3}[5,6]$.

Standardization was carried out: iodometrically $(\mathrm{Cu})$, complexometric $(\mathrm{Pb}),(\mathrm{Zn})$, gravimetrically $(\mathrm{Fe})$, permanganatometrically $(\mathrm{Fe})$, mercurimetrically $(\mathrm{Hg})[5,6]$.

A standard aqueous solution of phosphorus with a titer of $10 \mu \mathrm{g} / \mathrm{ml}$ was prepared by accurately adding mercurimetrically c. p. $0.24 \mathrm{M}$ aqueous solution of $\mathrm{Na}_{2} \mathrm{MoO}_{4} \cdot 2 \mathrm{H}_{2} \mathrm{O}$ was prepared by accurate weighing.

Metalchromic indicators were used: xylenol orange (XO), pyrocatechol violet (PCV), chromazurol S (CAZ), SPADNS a.r. (Chemapol), malachite green (MLG) a. r. (Merk), arsenazo III (ARS) c. p., acid chromium oxide (AC), a. r.

A standard aqueous solution of phosphorus with a titer of $10 \mu \mathrm{g} / \mathrm{ml}$ was prepared by accurately adding $\mathrm{KH}_{2} \mathrm{PO}_{4}$ c. p. $0.24 \mathrm{M}$ aqueous solution of $\mathrm{Na}_{2} \mathrm{MoO}_{4} \cdot 2 \mathrm{H}_{2} \mathrm{O}$ was prepared by accurate weighing.

$\mathrm{HC} 1, \mathrm{HNO}_{3}, \mathrm{NaOH}, \mathrm{NaCl}$, acetone, octanol e. p.; $35 \%$ hydrogen peroxide solution, c. $\mathrm{p}$.

Initial $1.0 \mathrm{~mol} / \mathrm{l}$ potassium solutions of thiocyanate and sodium fluoride were prepared by dissolving the exact samples of the corresponding preparations of qualification c.p. in water. Initial $1.0 \mathrm{~mol} / 1$ solutions of nitric and hydrochloric acids, $0.2 \mathrm{~mol} / 1$ sulfuric acid solution were prepared by dilution of concentrated solutions.

Work solutions were prepared by diluting the starting materials before the experiment.

The anion exchanger AB-17×8 (A) was used in the Cl-form with a $0.25-0.50 \mathrm{~mm}$ grain size, which was prepared using the procedure described in [5, 6]: 10 grams of A were soaked in a saturated $\mathrm{NaCl}$ solution and left for a day. The sorbent was then separated, washed with $0.5 \mathrm{M} \mathrm{HCl}$ solution until a negative reaction to $\times$ was observed and washed with water until neutral. The polymer matrix was modified with an aqueous solution of the metallochromic indicator, as described in $[5,6]$. To do this, $\sim 0.1 \mathrm{~g}$ of the indicator in $150 \mathrm{ml}$ of water was treated with $10 \mathrm{~g}$ of air-dry A-Cl. The solid was filtered off, washed with water, dried. The obtained solid-phase reagents ( $\overline{\mathrm{SPADNS}}, \overline{\mathrm{XO}}, \overline{\mathrm{PCV}}, \overline{\mathrm{MLG}}, \overline{\mathrm{CAZ}}, \overline{\mathrm{ARS}}, \overline{\mathrm{AC}}, \overline{\mathrm{ECC}})$ are transparent colored granules that pass light well.

The preparation of a solid sample for photometry consisted in obtaining a light-absorbing layer of concentrate, evenly distributed in the cuvette. Quartz cuvettes with parallel walls were used for the measurements. The concentrate was transferred with a pipette into a cuvette, which was first filled with water, another cuvette was similarly filled with an AB-17×8-Cl or an AB-17×8 indicator of the same grain. The light absorption of the analyzed samples was measured after the maximum packing density of the granules in the cuvettes was reached. Stirring of the solutions was carried out on a magnetic stirrer.

Methods and techniques of analysis. The content of $\mathrm{K}, \mathrm{Na}, \mathrm{Ca}$ was determined by the flame photometry method of the calibration curve. 
Method of phosphorus determination [14]. $0.1 \mathrm{ml}$ of the product ash solution was introduced into a conical tube of $10 \mathrm{ml}$ volume. $2 \mathrm{ml}$ of $2 \mathrm{M}$ nitric acid was added. $0.4 \mathrm{ml}$ of $0.24 \mathrm{M}$ sodium moe lybdate solution was added. Then, $1 \mathrm{ml}$ of a $0.1 \%$ aqueous solution of MLG was added. Water was added to the labels and mixed with a stick. At the same time dark green flakes of ionic associate of molybdophosphoric heteropolyacid with formed malachite green. The mixture was centrifuged for 2 minutes (3000 rpm). The centrifuge was drained. $10 \mathrm{ml}$ of water was added to the precipitate, it was mixed with a stick to wash the ion associate sludge from excess MLG, again, it was centrifuged for 2 minutes. The centrifuge was drained, $10 \mathrm{ml}$ of acetone was added to dissolve the precipitate, and the solution was transferred to a $100 \mathrm{ml}$ volumetric flask. Another $10 \mathrm{ml}$ of acetone was added to the tube to completely dissolve the sediment residues and transferred to a volumetric flask with the previous portion of the acetone solution of the ion associate. The solution in the flask was brought to the mark with water and stirred. The precipitate was completely dissolved. The optical density of the solution was measured in a cuvette with $\mathrm{l}=1 \mathrm{~cm}$ at $\lambda=620 \mathrm{~nm}$ with respect to water.

Method of $\mathrm{Fe}$ (III) determination [15]. In a $25 \mathrm{ml}$ volumetric flask, $1 \mathrm{ml}$ of the product ash solution was added, $2 \mathrm{ml}$ of a $2 \mathrm{M}$ nitric acid solution, $5 \mathrm{ml}$ of a $20 \%$ solution of ammonium thiocyanate were added, water was added to the mark, and mixed. The optical density was measured in a cuvette with $1=1 \mathrm{~cm}$ at $\lambda=490 \mathrm{~nm}$ relative to water.

Method of $\mathrm{Cu}$ (II) determination [5, 6]. A $1 \mathrm{ml}$ solution of the product ash was introduced into a $50 \mathrm{ml}$ measuring beaker. Then, $1 \mathrm{ml}$ of a $10^{-3} \mathrm{M}$ aqueous solution of SPADNS was added. $1 \mathrm{ml}$ of a $10^{-3} \mathrm{M}$ sodium fluoride solution was added to bind Fe (III) ions to a colorless complex. Distilled water was added up to $25 \mathrm{ml}$, creating a $\mathrm{pH}$ of 6.8 with urotropine and $\mathrm{NaOH}$. The optical density was measured in a cuvette with $l=1 \mathrm{~cm}$ at $\lambda=580 \mathrm{~nm}$ with respect to water.

Method of Zn (II) determination [5, 6]. A $50 \mathrm{ml}$ volume beaker was added with $1 \mathrm{ml}$ of a product ash solution, $20 \mathrm{ml}$ of distilled water in a $50 \mathrm{ml}$ volume, $\mathrm{pH} 2-2.5$ was created with $\mathrm{HCl}$ and $\mathrm{NaOH}, 0.3 \mathrm{~g}$ of solid phase MLG was added and mixed for 20 minutes on a magnetic stirrer. The solid phase was separated by filtration and discarded. In the liquid phase, $\mathrm{pH} 3$ was created using urotropinecrist. $0.3 \mathrm{~g}$ of solid phase MTS was added and mixed for 20 minutes on a magnetic stirrer. The optical density in the solid phase was measured in a cuvette with $1=0.1 \mathrm{~cm}$ at $\lambda=500 \mathrm{~nm}$ relative to $\mathrm{AB}-17 \times 8$.

Method of Cd (II) determination [6]. After the determination of Zn (II), the solid concentrate of the $\mathrm{Zn}$ (II) complex with MTS was separated by filtration and discarded. In the remaining liquid phase, a pH of 7 was created, $0.3 \mathrm{~g}$ of solid phase MTS was added, and the mixture was stirred for 20 minutes on a magnetic stirrer. The optical density was measured in a cuvette with $1=0.1 \mathrm{~cm}$ at $\lambda=640 \mathrm{~nm}$ relative to $\mathrm{AB}-17 \times 8$.

Method of $\mathrm{Pb}(\mathrm{II})$ determination [6]. A $1 \mathrm{ml}$ solution of the product ash was introduced into a $50 \mathrm{ml}$ measuring beaker. $20 \mathrm{ml}$ of distilled water was added. $1 \mathrm{ml}$ of a $10^{-3} \mathrm{M}$ sodium fluoride solution was added to bind $\mathrm{Fe}^{3+}$ ions. In a volume of $50 \mathrm{ml}, \mathrm{pH} 2$ was created with $\mathrm{HCl}$ and $\mathrm{NaOH} .0 .3 \mathrm{~g}$ of solid phase PCV was added and stirred for 20 minutes on a magnetic stirrer. The optical density of the solid phase was measured in a cuvette with $\mathrm{l}=0.1 \mathrm{~cm}$ at $\lambda=640 \mathrm{~nm}$, relative to AB- $17 \times 8$.

Method of $\mathrm{Hg}$ (II) determination [6]. A $1 \mathrm{ml}$ solution of the product ash was introduced into a $150 \mathrm{ml}$ measuring beaker. $20 \mathrm{ml}$ of distilled water was added. Then $1 \mathrm{ml}$ of a $10^{-3} \mathrm{M}$ sodium fluoride solution was added to bind $\mathrm{Fe}^{3+}$ ions. In a volume of $50 \mathrm{ml}, \mathrm{pH} 2$ was created with $\mathrm{HNO}_{3}$ and $\mathrm{NaOH}$. $0.3 \mathrm{~g}$ of solid phase CAZ was added and mixed for 20 minutes on a magnetic stirrer. The optical density of the solid phase was measured in a cuvette with $\mathrm{l}=0.1 \mathrm{~cm}$ at $\lambda=580 \mathrm{~nm}$ relative to AB- $17 \times 8$.

Sample preparation for SSS determinations $[5,6]$. A sample was introduced into a porcelain dish, dried in an oven at $\mathrm{t}=100{ }^{\circ} \mathrm{C}$ to constant weight, put in a muffle furnace for 2.5 hours. The temperature was increased every 15 minutes by $50{ }^{\circ} \mathrm{C}$ to $450{ }^{\circ} \mathrm{C} .10 \mathrm{ml}$ of $\mathrm{HNO}_{3}$ conc. and $5 \mathrm{ml}$ of a $35 \%$ solution of $\mathrm{H}_{2} \mathrm{O}_{2}$. Calcined for 40 minutes at $460{ }^{\circ} \mathrm{C}$. The resulting ash was dissolved in $10 \mathrm{ml}$ of $1 \mathrm{M} \mathrm{HNO}_{3}$, transferred to a $100 \mathrm{ml}$ volumetric flask and adjusted to a $1 \mathrm{M}$ mark with a nitric acid solution.

Ultrasonic destruction of samples [5, 6]. A sample of $25 \mathrm{~g}$ sample was crushed, divided into 6 parts, added to 6 heat-resistant flasks of $100 \mathrm{ml}$ volume. To each was added $10 \mathrm{ml}$ of $\mathrm{HNO}_{3}$ conc. and $5 \mathrm{ml}$ of a $35 \%$ solution of $\mathrm{H}_{2} \mathrm{O}_{2}$ were sonicated for 10 minutes, the resulting destruct 
materials were combined in a heat-resistant beaker, rinsing each flask in small portions of water and evaporating to wet salts. The latter were dissolved in $10 \mathrm{ml}$ of $1 \mathrm{M} \mathrm{HNO}_{3}$, transferred to a 100 $\mathrm{ml}$ volumetric flask and brought to the mark with water.

Equipment. The light absorption spectra of solutions were taken using a spectrophotometer SF-46 (Russia). The light absorption of the solutions was measured at KFK-3 (Russia) at the optimum wavelength $\left(\lambda_{\text {opt }}\right)$ relative to water or anion exchanger AB-17×8. The acidity of the solutions was controlled with an ionometer I-160 (Belarus) with a glass electrode. Polarographic determination of metals was carried out with the help of a voltammetric analyzer ABA-2 (Russia). The atomic-absorption determination of mercury was carried out with the help of the Yulia-2 analyzer. The radiation intensity was measured on a flame photometer FPL-01. Ultrasonic sample preparation was carried out in accordance with the recommendations set forth in [16], using the UP-1 of SELMI (acoustic power $20 \mathrm{~W} / \mathrm{cm}^{2}$, frequency $43 \mathrm{kHz}$ ) (Ukraine).

\section{Schemes of food analysis.}

SCHEME OF ANALYSIS No. 1 [17]:

1. Ultrasonic destruction of samples.

2. Evaporation of the destruct materials to wet salts.

3. Preparation of nitric acid solutions of metal salts.

4. Preparation of reagent solutions and synthesis of solid-phase dyes: ( $\overline{\mathrm{SPADNS}}, \overline{\mathrm{XO}}$, $\overline{\mathrm{PCV}}, \overline{\mathrm{MLG}}, \overline{\mathrm{CAZ}}, \overline{\mathrm{ARS}}, \overline{\mathrm{AC}}, \overline{\mathrm{ECC}}$ )

5. Determination of metals in individual portions of sample solutions.

6. Determination of Fe (III): extraction of Fe (III) ions in $\overline{\mathrm{ARS}}$ phase at $\mathrm{pH} 1.5$ and SSS determination.

7. Determination of $\mathbf{Z n}$ (II): removal of interfering cations in the $\overline{\mathrm{XO}}$ phase at $\mathrm{pH} 1.5$ and separation of the solid phase; separation of $\mathrm{Zn}$ (II) from Cd (II) in the liquid phase that remained (recovery of Cd (II) into $\overline{\mathrm{AC}}$ phase at $\mathrm{pH} 4.0$ and separation of the solid phase); Determination of $\mathrm{Zn}$ (II) in the liquid phase with $\mathrm{XO}$ at $\mathrm{pH}$ 5.5.

8. Determination of $\mathbf{C u}$ (II) extraction of $\mathrm{Cu}$ (II) ions in phase $\overline{\text { SPADNS }}$ at $\mathrm{pH} 6.0$ and SSS determination.

9. Determination of $\mathbf{P b}$ (II): extraction of $\mathrm{Pb}$ (II) ions in $\overline{\mathrm{PCV}}$ phase at $\mathrm{pH} 1.5$ and SSS determination.

10. Determination of Cd (II): removal of interfering cations in the $\overline{\mathrm{ECB}}$ phase at $\mathrm{pH} 4.0$ and separation of the solid phase; extraction of $\mathrm{Cd}$ (II) ions from the remaining liquid phase into a new portion at $\mathrm{pH} 9.0$ and SSS determination.

11. Determination of $\mathbf{H g}$ (II): extraction of $\mathrm{Hg}$ (II) ions in $\overline{\mathrm{CAZ}}$ phase at $\mathrm{pH} 1.5$ and SSS determination.

12. Determination of K (I), Na (I), Ca (II) by the method of flame photometry.

SCHEME OF ANALYSIS No. 2: $\mathrm{t}=460{ }^{\circ} \mathrm{C}$

1. Drying the samples in the furnace at $\mathrm{t}=100{ }^{\circ} \mathrm{C}$ and ashing in the muffle furnace at

2. Preparation of nitric acid solutions of ash for the determination of trace elements in individual portions.

3. Preparation of reagent solutions and synthesis of solid-phase dyes: ( $\overline{\text { SPADNS }}, \overline{\mathrm{XO}}$, $\overline{\mathrm{PCV}}, \overline{\mathrm{MLG}}, \overline{\mathrm{CAZ}}, \overline{\mathrm{ARS}}, \overline{\mathrm{AC}}, \overline{\mathrm{ECC}}$ ).

4. Determination of metals in individual portions of sample solutions.

5. Determination of Fe (III): extraction of Fe (III) ions in $\overline{\mathrm{ARS}}$ phase at pH 1.5 and SSS determination.

6. Determination of $\mathbf{Z n}$ (II): removal of interfering cations in the $\overline{\mathrm{XO}}$ phase at $\mathrm{pH} 1.5$ and separation of the solid phase; separation of $\mathrm{Zn}$ (II) from Cd (II) in the liquid phase that remained (recovery of $\mathrm{Cd}$ (II) into $\overline{\mathrm{AC}}$ phase at $\mathrm{pH} 4.0$ and separation of the solid phase); Determination of $\mathrm{Zn}$ (II) in the liquid phase with $\mathrm{XO}$ at $\mathrm{pH} 5.5$.

7. Determination of $\mathbf{C u}$ (II) extraction of $\mathrm{Cu}$ (II) ions in phase $\overline{\mathrm{SPADNS}}$ at $\mathrm{pH} 6.0$ and SSS determination. 
8. Determination of $\mathbf{P b}$ (II): extraction of $\mathrm{Pb}$ (II) ions in $\overline{\mathrm{PCV}}$ phase at $\mathrm{pH} 1.5$ and SSS determination.

9. Determination of $\mathbf{C d}$ (II): removal of interfering cations in the $\overline{\mathrm{ECB}}$ phase at $\mathrm{pH} 4.0$ and separation of the solid phase; extraction of $\mathrm{Cd}$ (II) ions from the remaining liquid phase into a new portion at $\mathrm{pH} 9.0$ and SSS determination.

10. Determination of $\mathbf{H g}$ (II): extraction of $\mathrm{Hg}$ (II) ions in $\overline{\mathrm{CAZ}}$ phase at $\mathrm{pH} 1.5$ and SSS determination.

11. Determination of K (I), Na (I), Ca (II) by the method of flame photometry.

SCHEME OF ANALYSIS No. 3:

1. Ultrasonic destruction of samples.

2. Evaporation of the destruct materials to wet salts.

3. Preparation of nitric acid solutions of metal salts. $\overline{\mathrm{ECB}}, \overline{\mathrm{AC}}$

4. Preparation of reagent solutions and synthesis of solid-phase dyes: $\overline{\mathrm{PCF}}, \overline{\mathrm{CAZ}}, \overline{\mathrm{XO}}$,

5. Determination of metals in individual portions of sample solutions.

6. Determination of Fe (III): Photometric determination of Fe(III) with ammonium thiocyanate.

7. Determination of $\mathbf{Z n}$ (II): removal of interfering cations in the $\overline{\mathrm{XO}}$ phase at $\mathrm{pH} 1.5$ and separation of the solid phase; separation of $\mathrm{Zn}$ (II) from Cd (II) in the liquid phase that remained (recovery of $\mathrm{Cd}$ (II) into $\overline{\mathrm{AC}}$ phase at $\mathrm{pH} 4.0$ and separation of the solid phase); Determination of $\mathrm{Zn}$ (II) in the liquid phase with $\mathrm{XO}$ at $\mathrm{pH} 5.5$.

8. Determination of $\mathbf{C u}$ (II) binding of Fe (III) ions to a colorless fluoride complex, photometric determination by means of SPADNS at $\mathrm{pH}$ 6.0.

9. Determination of $\mathbf{P b}$ (II): extraction of $\mathrm{Pb}$ (II) ions in $\overline{\mathrm{PCV}}$ phase at $\mathrm{pH} 1.5$ and SSS determination.

10. Determination of Cd (II): removal of interfering cations in the $\overline{\mathrm{ECB}}$ phase at $\mathrm{pH} 4.0$ and separation of the solid phase; extraction of $\mathrm{Cd}$ (II) ions from the remaining liquid phase into a new portion at $\mathrm{pH} 9.0$ and SSS determination.

11. Determination of $\mathbf{H g}$ (II): extraction of $\mathrm{Hg}$ (II) ions in $\overline{\mathrm{CAZ}}$ phase at $\mathrm{pH} 1.5$ and SSS determination.

12. Determination of K (I), Na (I), Ca (II) by the method of flame photometry.

SCHEME OF ANALYSIS No. 4:

1. Drying the samples in the furnace at $\mathrm{t}=100^{\circ} \mathrm{C}$ and ashing in the muffle furnace at $\mathrm{t}=460{ }^{\circ} \mathrm{C}$.

2. Preparation of nitric acid solutions of poppy seeds for the determination of trace elements in individual portions.

3. Preparation of reagent solutions and synthesis of solid-phase dyes: $\overline{\mathrm{PCV}}, \overline{\mathrm{CAZ}}, \overline{\mathrm{XO}}, \mathrm{MLG}$.

4. Determination of $\mathbf{P}(\mathbf{V})$ : The photometric determination of $P(V)$ as an ionic associate of a molybdophosphoric heteropolyacid with a malachite green.

5. Determination of Fe (III): Photometric determination of Fe (III) with ammonium thiocyanate.

6. Determination of $\mathbf{C u}$ (II): binding of Fe (III) ions to a colorless fluoride complex, photometric determination using SPADNS at $\mathrm{pH}$ 6.0.

7. Determination of $\mathbf{P b}$ (II): binding of Fe (III) ions to a colorless fluoride complex, SSS determination using at $\mathrm{pH} 2$.

8. Determination of $\mathbf{Z n}$ (II): removal of interfering cations in the $\overline{\mathrm{XO}}$ phase at $\mathrm{pH} 2-2.5$ and separation of the solid phase. Creation of $\mathrm{pH} 3$ in the liquid phase, SSS determination of $\mathrm{Zn}$ (II) with $\overline{\mathrm{MLG}}$.

9. Determination of $\mathbf{C d}$ (II): removal of interfering cations in the $\overline{\mathrm{XO}}$ phase at $\mathrm{pH} 2-2.5$ and separation of the solid phase. Creation of $\mathrm{pH} 3$ in the liquid phase, separation of $\mathrm{Zn}$ (II) with $\overline{\mathrm{MLG}}$. Creation of $\mathrm{pH} 7$ in the liquid phase and SSS determination of Cd (II) with $\overline{\mathrm{MLG}}$.

10. Determination of $\mathbf{H g}$ (II): binding of Fe (III) ions to a colorless fluoride complex, SSS determination using $\overline{\mathrm{CAZ}}$ at $\mathrm{pH} 2$.

11. Determination of K (I), Na (I), Ca (II) by the method of flame photometry. 


\section{SCHEME OF ANALYSIS No. 5:}

1. Ultrasonic destruction of samples.

2. Evaporation of the destruct materials to wet salts.

3. Preparation of nitric acid solutions of metal salts.

4. Preparation of reagent solutions and synthesis of solid-phase dyes: $\overline{\mathrm{PCV}}, \overline{\mathrm{CAZ}}, \overline{\mathrm{XO}}, \overline{\mathrm{MLG}}$.

5. Determination of $\mathbf{P}(\mathbf{V})$ : The photometric determination of $P(V)$ as an ionic associate of a molybdophosphoric heteropolyacid with malachite green.

6. Determination of Fe (III): Photometric determination of Fe (III) with ammonium thiocyanate.

7. Determination of $\mathbf{C u}$ (II): binding of Fe (III) ions to a colorless fluoride complex, photometric determination by means of SPADNS at $\mathrm{pH}$ 6.0.

8. Determination of $\mathbf{P b}$ (II): binding of Fe (III) ions to a colorless fluoride complex, SSS determination using $\overline{\mathrm{PCV}}$ at $\mathrm{pH} 2$.

9. Determination of $\mathbf{Z n}$ (II): removal of interfering cations in the phase $\overline{\mathrm{XO}}$ at $\mathrm{pH} 2-2.5$ and separation of the solid phase. Creation of $\mathrm{pH} 3$ in the liquid phase, SSS determination of Zn (II) with $\overline{\mathrm{MLG}}$.

10. Determination of Cd (II): removal of interfering cations in the phase $\overline{\mathrm{XO}}$ at $\mathrm{pH} 2-2.5$ and separation of the solid phase. Creation of $\mathrm{pH} 3$ in the liquid phase, separation of $\mathrm{Zn}$ (II) with $\overline{\mathrm{MLG}}$. Creation of $\mathrm{pH} 7$ in the liquid phase and SSS determination of Cd (II) with $\overline{\mathrm{MLG}}$.

11. Determination of $\mathbf{H g}$ (II): binding of Fe (III) ions to a colorless fluoride complex, SSS determination using $\overline{\mathrm{CAZ}}$ at $\mathrm{pH} 2$.

12. Determination of K (I), Na (I), Ca (II) by the method of flame photometry.

SCHEME OF ANALYSIS No. 6:

1. "Wet" sample preparation using $\mathrm{HNO}_{3}$ conc. and $35 \% \mathrm{H}_{2} \mathrm{O}_{2}$.

2. Preparation of nitric acid solutions of metal salts.

3. Preparation of reagent solutions and synthesis of solid-phase dyes: $\overline{\mathrm{PCV}}, \overline{\mathrm{CAZ}}, \overline{\mathrm{XO}}, \overline{\mathrm{MLG}}$.

4. Determination of $\mathbf{P}(\mathbf{V})$ : The photometric determination of $P(V)$ as an ionic associate of a molybdophosphoric heteropolyacid with malachite green.

5. Determination of Fe (III): Photometric determination of Fe (III) with ammonium thiocyanate.

6. Determination of $\mathbf{C u}$ (II): binding of Fe (III) ions to a colorless fluoride complex, photometric determination using SPADNS at $\mathrm{pH}$ 6.0.

7. Determination of $\mathbf{P b}$ (II): binding of Fe (III) ions to a colorless fluoride complex, SSS determination using $\overline{\mathrm{PCV}}$ at $\mathrm{pH} 2$.

8. Determination of $\mathbf{Z n}$ (II): removal of interfering cations in the phase $\overline{\mathrm{XO}}$ at $\mathrm{pH} 2-2.5$ and separation of the solid phase. Creation of $\mathrm{pH} 3$ in the liquid phase $\overline{\mathrm{MLG}}$, SSS determination of $\mathrm{Zn}$ (II) with $\overline{\mathrm{MLG}}$.

9. Determination of $\mathbf{C d}$ (II): removal of interfering cations in the phase $\overline{\mathrm{XO}}$ at $\mathrm{pH} 2-2.5$ and separation of the solid phase. Creation of $\mathrm{pH} 3$ in the liquid phase, separation of $\mathrm{Zn}$ (II) with $\overline{\mathrm{MLG}}$. Creation of $\mathrm{pH} 7$ in the liquid phase and SSS determination of Cd (II) with $\overline{\mathrm{MLG}}$.

10. Determination of $\mathbf{H g}$ (II): binding of Fe (III) ions to a colorless fluoride complex, SSS determination using $\overline{\mathrm{CAZ}}$ at $\mathrm{pH} 2$.

11. Determination of K (I), Na (I), Ca (II) by the method of flame photometry.

SCHEME OF ANALYSIS No. 7:

1. "Wet" sample preparation using $\mathrm{HNO}_{3}$ conc. and $35 \% \mathrm{H}_{2} \mathrm{O}_{2}$.

2. Preparation of nitric acid solutions of metal salts.

3. Preparation of reagent solutions and synthesis of solid-phase dyes: $\overline{\mathrm{PCV}}, \overline{\mathrm{CAZ}}, \overline{\mathrm{XO}}$, $\overline{\mathrm{ECB}}, \overline{\mathrm{AC}}, \overline{\mathrm{ARS}}, \overline{\mathrm{SPADNS}}$.

4. Determination of metals in individual portions of sample solutions.

5. Determination of Fe (III): extraction of Fe (III) ions in phase $\overline{\mathrm{ARS}}$ at $\mathrm{pH} 1.5$ and SSS determination.

6. Determination of $\mathbf{Z n}$ (II): removal of interfering cations in the phase $\overline{\mathrm{XO}}$ at $\mathrm{pH} 1.5$ and separation of the solid phase; separation of $\mathrm{Zn}$ (II) from $\mathrm{Cd}$ (II) in the liquid phase that remained 
(recovery of $\mathrm{Cd}$ (II) into phase $\overline{\mathrm{AC}}$ at $\mathrm{pH} 4.0$ and separation of the solid phase); Determination of $\mathrm{Zn}$ (II) in the liquid phase with $\mathrm{XO}$ at $\mathrm{pH}$ 5.5.

7. Determination of $\mathrm{Cu}$ (II): extraction of $\mathrm{Cu}$ (II) ions in phase $\overline{\mathrm{SPADNS}}$ at $\mathrm{pH} 6.0$ and SSS determination.

8. Determination of $\mathbf{P b}$ (II): extraction of $\mathrm{Pb}$ (II) ions in phase $\overline{\mathrm{PCV}}$ at $\mathrm{pH} 1.5$ and SSS determination.

9. Determination of $\mathbf{C d}$ (II): removal of interfering cations in the phase $\overline{\mathrm{ECB}}$ at $\mathrm{pH} 4.0$ and separation of the solid phase; extraction of $\mathrm{Cd}$ (II) ions from the liquid phase that remained in the new portion $\overline{\mathrm{ECB}}$ ) at $\mathrm{pH} 9.0$ and SSS determination.

10. Determination of $\mathbf{H g}$ (II): extraction of $\mathrm{Hg}$ (II) ions in phase $\overline{\mathrm{CAZ}}$ at $\mathrm{pH} 1.5$ and SSS determination.

11. Determination of K (I), Na (I), Ca (II) by the method of flame photometry.

\section{Discussion of schemes of microelement analysis of food objects}

It can be seen that schemes No. 1 and No. 2 differ by sample preparation of the samples analyzed. In the first case, ultrasound is applied to the samples. This makes it possible to significantly shorten the time of the experiment. Thus, in work [17] scheme No. 1 was applied to the analysis of fungi. In this case, ultrasonic degradation (ultrasound) occurs within $30 \ldots 40$ minutes. The increase in the power of ultrasonic radiation reduces the time for sample preparation by 2 times. The use of solid-phase reagents $\overline{\mathrm{PCV}}, \overline{\mathrm{CAZ}}, \overline{\mathrm{XO}}, \overline{\mathrm{ECB}}, \overline{\mathrm{AC}}, \overline{\mathrm{ARS}}, \overline{\mathrm{SPADNS}}$ to determine the microquantities of metal ions allows them to concentrate from large volumes of solutions and thus increase the sensitivity of the determination.

Scheme No. 3 provides, in addition to accelerated sample preparation, a simple photometric determination of $\mathrm{Cu}$ (II) and Fe (III) in solution.

In the analysis of Scheme 4, solid-phase reagents $\overline{\mathrm{PCV}}, \overline{\mathrm{CAZ}}, \overline{\mathrm{XO}}, \overline{\mathrm{MLG}}$ photometric determination of $\mathrm{Cu}$ (II) and Fe (III) in solution are used, as in scheme No. 3. The methods of separation and determination of $\mathrm{Zn}$ (II) and Cd (II) have been changed. A highly sensitive method for determining phosphorus was introduced into the scheme. Scheme No. 4 was successfully tested for the analysis of poppy seeds.

The analysis according to Scheme No. 5 differs from Scheme No. 4 using ultrasonic sample preparation.

In the case of analysis according to Schemes Nos. 6 and 7, "wet" sample preparation is provided. Scheme No. 6 uses solid-phase reagents $\overline{\mathrm{PCV}}, \overline{\mathrm{CAZ}}, \overline{\mathrm{XO}}, \overline{\mathrm{ECB}}, \overline{\mathrm{AC}}, \overline{\mathrm{ARS}}, \overline{\mathrm{SPADNS}}$. In the scheme number 7-reagents $\overline{\mathrm{PCV}}, \overline{\mathrm{CAZ}}, \overline{\mathrm{XO}}, \overline{\mathrm{MLG}}$ are used.

\section{Conclusions}

Approaches to development of schemes for microelement analysis of food objects are considered, which consist in the following: obtaining information on the interaction of the elements being determined with various reagents in solution. Then study the possibility of carrying out similar reactions in the sorbent phase. Based on the obtained data, solid-phase reagents are created. After studying the chemical-analytical characteristics of the latter, use them to develop techniques for determining the various elements in the objects.

Based on the systematization of information on the interaction of the detectable elements with various reagents in the solution and phase of the polymer anion exchanger $\mathrm{AB}-17 \times 8,7$ schemes of microelement analysis of food products are developed.

In the case of determining $\mathrm{Hg}$ (II), analytical schemes should be used that provide for ultrasonic or "wet" sample preparation. At the same time, the temperature is much lower than for "dry" (thermal) preparation and the loss of $\mathrm{Hg}$ (II) will be the least, and the results are the most reliable.

The most effective for the separation and determination of $\mathrm{Zn}$ (II) and $\mathrm{Cd}$ (II) are $\overline{\mathrm{XO}}, \overline{\mathrm{MLG}}$.

The concentration and separation of interfering ions with the case of the determination of toxic metals ( $\mathrm{Pb}$ (II), $\mathrm{Cd}$ (II), $\mathrm{Hg}$ (II)) is most effective in acidic media.

The most sensitive and selective reagents $(\overline{\mathrm{PCV}}, \overline{\mathrm{CAZ}}, \overline{\mathrm{XO}}, \overline{\mathrm{ECB}}, \overline{\mathrm{AC}}, \overline{\mathrm{ARS}}, \overline{\mathrm{SPADNS}})$ for determination of $\mathrm{Pb}$ (II), $\mathrm{Cd}$ (II), $\mathrm{Hg}$ (II), Zn (II), $\mathrm{Cu}$ (II), Fe (III), P (V). The developed analysis 
schemes will make it possible to monitor food quality by simple and accessible methods in factory laboratories. The solid-phase reagents used can be easily synthesized under the conditions of the factory laboratory.

\section{References}

[1] Yatmanova, A. A. (2015). Formirovanie kachestva pishhevykh produktov v protsesse proizvodstva. Novaya nauka: Ot idei k rezultatu, 7-1, 253.

[2] Mikhienkova, A. I., Rosada, M. A., Surmasheva, E. V., Berezovchuk, S. M., Nikonova, N. A. (2013). Evropeyskie podkhody k otsenke bezopasnosti pish hevykh produktov po mikrobiologicheskim pokazatelyam. Gigiena i sanitariya, 5, 48-53.

[3] Tuvatova, V. E. (2016). Kontrol' kachestva i bezopasnosti produktsii iz rybnogo syr'ya. Innovatsionnaya nauka, 6-2, 153-155.

[4] Dubinina, A. A., Ovchynnikova, I. F., Dubinina, S. O. et. al. (2010). Metody vyznachennia falsyfikatsii tovariv. Kyiv: Profesional, 272.

[5] Kostenko, Ye. Ye. (2011). Khimiko-analitychni vlastyvosti azobarvnykiv, immobilizovanykh na anioniti AB-17×8, ta vykorystannia yikh v analizi kharchovykh obiektiv. Ukrainskyi khimichnyi zhurnal, 77 (8), 107-115.

[6] Kostenko, Ye. Ye. (2011). Khimiko-analitychni vlastyvosti sulfoftaleinovykh barvnykiv, immobilizovanykh na anioniti AB-17×8 ta yikh vykorystannia v analizi kharchovykh obiektiv. Metody ta Obiekty Khimichnoho Analizu, 6 (1-2), 56-70.

[7] Camel, V. (2003). Solid phase extraction of trace elements. Spectrochimica Acta Part B: Atomic Spectroscopy, 58 (7), 1177-1233. doi: 10.1016/s0584-8547(03)00072-7

[8] Liska, I. (2000). Fifty years of solid-phase extraction in water analysis - historical development and overview. Journal of Chromatography A, 885 (1-2), 3-16. doi: 10.1016/s0021-9673(99)01144-9

[9] Poole, C. F. (2000). Solid-Phase Extraction. Encyclopedia of Separation Science. Academic Press, 1405-1416. doi: 10.1016/b0-12-226770-2/02141-4

[10] Rocha, F. R. P., Raimundo, I. M., Teixeira, L. S. G. (2011). Direct Solid-Phase Optical Measurements in Flow Systems: A Review. Analytical Letters, 44 (1-3), 528-559. doi: 10.1080/00032719.2010.500790

[11] Arena, M. P., Porter, M. D., Fritz, J. S. (2002). Rapid, Specific Determination of Iodine and Iodide by Combined Solid-Phase Extraction/Diffuse Reflectance Spectroscopy. Analytical Chemistry, 74 (1), 185-190. doi: 10.1021/ac0109366

[12] Lubbad, S., Steiner, S. A., Fritz, J. S., Buchmeiser, M. R. (2006). Metathesis polymerization-derived monolithic membranes for solid-phase extraction coupled with diffuse reflectance spectroscopy. Jourd nal of Chromatography A, 1109 (1), 86-91. doi: 10.1016/j.chroma.2005.11.082

[13] Sukhan, V. V., Trokhimenko, O. M., Zaitsev, V. N. (2010). Direct and indirect atomic absorption methods of determining various forms of iodine in waters and in aqueous solutions. Journal of Water Chemg istry and Technology, 32 (2), 78-89. doi: 10.3103/s1063455x10020037

[14] Trokhymenko, O. M. (2002). Fotometrychne vyznachennia fosforu (V) u vyhliadi ionnoho asotsiatu molibdofosfatu z diamantovym zelenym. Ukrainskyi khimichnyi zhurnal, 68 (6), 88-91.

[15] Kostenko, Ye. Ye., Khrystiansen, M. H., Shtokalo, M. Y. et. al. (2009). Analitychna khimiia. Optychni ta elektrokhimichni metody analizu. Kyiv: NUKhT, 283.

[16] Chmylenko, F. A., Baklanov, A. N. (2001). Ultrazvuk v analytycheskoi khymyy. Teoryia y praktyka. Dnepropetrovsk: RYTs Dnepropetr. un-ta, 263.

[17] Kostenko, E. E. (2011). Viznachennya mikroelementnogo skladu gribiv metodom tverdofaznoi spektrofotometrii. Metody i ob»ekty khimicheskogo analiza, 6 (4), 214-223. 